\title{
Water Deficit in Iraq: Causes and Solutions
}

\section{Bassam AAH Alkhateb*}

Assistant Professor, College of Agriculture, University of Anbar, Iraq

*Corresponding Author: Bassam AAH Alkhateb, Assistant Professor, College of Agriculture, University of Anbar, Iraq.

Received: September 23, 2019; Published: October 18, 2019

DOI: 10.31080/ASAG.2019.03.0687

Iraq is located East of the Arab world and bordered by Iran to the East and Turkey to the North, covers an area of 437.072 square kilometers, and with population of Iraq 39.33 million population [1]. Most of the water resources originate from outside sources of the country, exposing the flow of water facing threats from political considerations and regional alliances. The water resources of Iraq depends on the Tigris and Euphrates rivers flowing from Turkey northward to the South. Most of the rivers come from Turkey (71\%), followed by Iran (6.9\%), Syria (4\%), and the rest sources are inside Iraq [2]. Iraq is rich in water resources because of the Tigris and Euphrates, but it has a water deficit, so requires the differentiation between the concept of water poverty and water deficit confirms that the departure of millions of acres of agricultural use because of poor water management. The growing population and the lack of good cooperation with the organizations and politicize the water issue make the future of the water issue very dangerous.

Iraq is passing into a major water crisis, one of the most important reasons is the establishment of dams on the Tigris and Euphrates rivers, Turkey has implemented a GAP project, which includes 22 dams and 19 power plants and increased irrigated area on the Tigris and Euphrates rivers included 25 irrigation systems. This project disrupts agricultural development plans in Iraq and Syria [3], reduced costs lead to deterioration in the quality of water used. A UN report in 2010 indicated that the Tigris and Euphrates rivers would dry up when they reach Iraq if neighboring countries continue to implement their water projects [4]. Therefore, the water quotas of each country should be given great attention to their impact on their development plans and strategies. Iraq and the region suffered from drought as temperatures recorded a record high, which negatively affects the population and agriculture in the region, and the amount of rainfall decreases with time [5].
The aggravation of the water crisis is summarized by the big difference between the water revenues and the quantities required for urban, agricultural and industrial purposes. The amount of dissolved salts in the waters of the Tigris River at the Iraqi-Turkish border is acceptable up to $280 \mathrm{mg} / \mathrm{l}$, but it increases significantly as the river head to South, while the water of the Euphrates River, the amount of dissolved salts at the Iraqi-Syrian border is about $600 \mathrm{mg} / \mathrm{l}$ and increases South To reach more than $1300 \mathrm{mg} / \mathrm{l}$ at Samawah [6]. Declining river drainage, poor water quality and increased soil salinity have transformed large areas of land into arid soils. Around $45 \%$ of Iraq's land is believed to have been affected by desertification. A person left their land between 2007 and 2009 [7]. Limited water resources, drought, worsening desertification, poor management of water resources, lack of use of modern irrigation systems in agriculture and lack of rationalization of water use are among the most important factors that have led to a food gap [8].

\section{Solutions}

Improving relations with Turkey and Syria and solving problems and differences due to the construction of dams on the Tigris and Euphrates rivers necessitates building economic relations with upstream countries and not venture to lose this relationship and return to exploit the water file. Use of Modern irrigation methods are one way to reduce the aggravation of the water crisis. The need to use modern methods that reduce water losses through the maintenance and development of irrigation networks and water distribution and try to use coated channels to reduce water losses. International and regional organizations should be utilized in the field of water resources management and investment.

Different remedy measure could be recommended; first of all different pilot research projects could be carried out in order to 
take advantage of advanced technology and make appropriate use of it through conducting pilot experiments with non-conventional methods of water collection. Secondly, establishing an information bank containing all relevant information and allowing researchers and graduate students to use it. Thirdly, effective participation in the World Water Day, organized by the United Nations Commission on Water Resources (UNCWR) and in cooperation with international parties, aims to raise awareness of the optimal utilization of water resources and discuss ways to address future challenges.

\section{Bibliography}

1. World meters. "Iraq population". (2018).

2. Al-Ansari NA. "Management of Water Resources in Iraq: Perspectives and Prognoses". Journal of Engineering 5.8 (2013): 667-684.

3. Guijani R. The Water Issue in Syria, National Information Center, Damascus (1994).

4. UN (United Nations). "Water Resources Management White Paper". United Nations Assistance Mission for Iraq, United Nations Country Team in Iraq (2010): 20.

5. Al-Ansari NA., et al. "Long Term Effect of Climate Change on Rainfall in Northwest Iraq". Central European Journal of Engineering 4.3 (2014): 250-263.

6. World Bank (2006).

7. Ali SM., et al. "Fluctuating rainfall as one of the important cause for desertification in Iraq". Journal of Environment and Earth Science 3.2 (2013): 25-33.

8. The Unified Arab Economic Report in the Arab World - Prospects and Future Prospects, Emirates Center for Strategic Studies and Research (1997).

Volume 3 Issue 11 November 2019

(C) All rights are reserved by Bassam AAH Alkhateb. 